\title{
Diagnostic utility of oxidative damage markers for early rheumatoid arthritis in non-smokers and negative anti-CCP patients
}

\section{Utilidad diagnóstica de los marcadores de estrés oxidativo en artritis reumatoide precoz en pacientes no fumadores y anti-CCP negativos}

\author{
E. Melguizo1, V. Navarro ${ }^{2,3}$, B. Hernández ${ }^{2,}$ K. Santos ${ }^{1}$, T. Arrobas ${ }^{1,4}$ C. Domínguez ${ }^{2}$, \\ F. Navarro' ${ }^{2}$, C. González ${ }^{1}$.
}

\section{RESUMEN}

Fundamento. A pesar del desarrollo de nuevos marcadores y criterios diagnósticos para la artritis reumatoide (AR), todavía muchos pacientes son diagnosticados tras varios años de síntomas. Los marcadores de estrés oxidativo se incrementan ya en una fase temprana de la enfermedad. El objetivo del presente estudio fue evaluar el valor diagnóstico adicional de estos marcadores. Método. Se realizó un estudio de casos y controles. Los pacientes reclutados para el estudio cumplían los criterios para AR de la ACR 1987, todos ellos tenían menos de 2 años de síntomas y sin tratamiento previo con fármacos modificadores de la enfermedad antirreumática (DMARD), esteroides o vitamina E. Los controles fueron seleccionados de los familiares del paciente y pareados (1:1) por sexo, edad, hábito tabáquico actual. Los marcadores de daño oxidativo que se midieron fueron malonildialdehído (MDA), hidroperóxidos lipídicos (LOOH) y proteínas carboniladas (CP). El Análisis estadístico se realizó de acuerdo con la STARD.

Resultados. Se incluyeron sesenta y cinco pacientes con AR sin tratamiento y 65 controles sanos. $\mathrm{LOOH}, \mathrm{CP}$, los anticuerpos con péctidos citrulinados (anti-CCP) y el factor reumatoide (FR) fueron significativamente mayores en los pacientes, y MDA fue mayor en los controles. Los mismos resultados se obtuvieron en los subgrupos de pacientes que fuman o no, y en anti-CCP positivos o negativos. El valor diagnóstico de los marcadores tradicionales mostró una buena especificidad pero una baja sensibilidad. La construcción de los modelos logísticos con la adicción de LOOH y CP aumenta la sensibilidad y el área bajo la curva ROC, especialmente en los no fumadores (66\%) y los pacientes negativos ante-CCP (51\%).

Conclusiones. $\mathrm{Al}$ incorporar $\mathrm{LOOH}$ o $\mathrm{CP}$ a los marcadores de la enfermedad tradicionales en $\mathrm{AR}$, bien por separado o ambos conjuntamente, mejoró el diagnóstico de AR, especialmente en los pacientes no fumadores o aquellos con anticuerpos antiCCP negativos.

Palabras clave. Sensibilidad. Hidroperóxido lipídico. Proteína carbonilada. Tabaco. Artritis reumatoide.

\begin{abstract}
Background. Besides the development of new markers and diagnostic criteria for rheumatoid arthritis (RA), many patients are still diagnosed after several years of symptoms. Oxidative stress markers are already increased at an early stage of RA. Our aim was to evaluate the additional diagnostic value of these markers.
\end{abstract}

Methods. A case-control study was performed. Patients met the 1987 RA ACR criteria, less than 2 years of symptoms and no previous treatment with disease-modifying anti-rheumatic drugs (DMARD), steroids or vitamin E. Controls were selected from patient's relatives and matched (1:1) by gender, age, and current smoking habit. Oxidative damage markers were malonyldialdehyde (MDA), Lipid hydroperoxides $(\mathrm{LOOH})$ and Carbonyl proteins (CP). Statistical analysis was performed in agreement with the STARD initiative.

Results. Sixty-five RA patients without treatment and 65 healthy controls were included. $\mathrm{LOOH}, \mathrm{CP}$, antibodies against citrullinated peptides (anti-CCP) and rheumatoid factor (RF) were significantly higher in patients, and MDA higher in controls. The same results were obtained in the subgroups of patients who smoke or not, and in anti-CCP positive or negative. The diagnosis performance of traditional markers showed good specificity but low sensitivity. The addition of $\mathrm{LOOH}$ and $\mathrm{CP}$ increased the sensitivity and the area under the receiving operating characteristic (ROC) curve especially in non-smoking $(66 \%)$ and negative anti-CCP (51\%) patients.

Conclusions. The separate or combined addition of $\mathrm{LOOH}$ or $\mathrm{CP}$ to the traditional disease markers improved the diagnosis of RA, especially in non-smoking or negative anti-CCP patients.

Key words. Sensitivity. Lipid hydroperoxide. Carbonyl protein. Smoking. Rheumatoid arthritis.
1. Clinical Biochemistry Department. University Hospital Virgen Macarena. Sevilla. Spain

2. Rheumatology Department, University Hospital Virgen Macarena. Sevilla. Spain

3. Department of Rheumatology. Leiden University Medical Center. Leiden. The Netherlands

4. Medicine, kinesiology and obstetric faculty, Autonomous University of Chile. Chile

Recepción: 5 de septiembre de 2013

Aceptación provisional: 18 de noviembre de 2013

Aceptación definitiva: 13 de enero de 2014

\section{Correspondencia:}

Enrique Melguizo Madrid

Clinical Biochemistry Department

University Hospital Virgen Macarena

Doctor Fedriani Avda. 3

41071 Sevilla. Spain

enriquemelguizo@yahoo.es

Funding

This work was supported by grants from the Instituto de Salud Carlos III (PI08/1353), the Virgen Macarena Foundation (ASVM 01/2009), and José Luis Castaño Foundation 


\section{INTRODUCTION}

Despite the development of new specific markers and diagnostic criteria ${ }^{1}$, there is still an unacceptable delay in the diagnosis of RA, related to permanent disability. Moreover, smoking is the most important environmental factor involved in RA pathogenesis ${ }^{2,3}$ and a source of free radicals ${ }^{4}$, causing oxidative stress which is defined as the imbalance between the oxidative and anti-oxidative pathways of the body. Furthermore, it has been shown that oxidative stress is related with the emergence and development of $\mathrm{RA}^{5,6}$ and it may act even before the onset of the disease ${ }^{7,8}$. Therefore, our hypothesis is that oxidative damage markers could be useful to diagnose RA patients in an early stage.

The aim of this study was to assess the additional diagnostic value of oxidative damage markers in diagnosing RA combined with the traditional biochemical markers in patients with recent-onset RA. Secondly, we compared the accuracy of oxidative damage markers based on the smoking habit and the presence or absence of anti-CCP.

\section{MATERIAL AND METHODS}

\section{Patients and samples}

A case-control study was performed (January 2009 - February 2011), according to the local regulations and the Declaration of Helsinki. Written informed consent was obtained before the inclusion from every enrolled subject. Individuals included in this study were selected from the Early Arthritis Office at the Rheumatology Department. RA patients met 1987 ACR criteria, had less than 2 years of symptoms and had not previously been treated with vitamin E, DMARDs or steroids. Controls were non-blood relatives' of the patients without chronic or inflammatory disease, matched 1:1 by gender, age ( \pm 4 years), and current smoking habit.

Demographic characteristics, smoking habit, disease related variables (in patients) and blood samples (into heparinized and non-heparinized tubes) were collected at one visit in all individuals. Samples were centrifuged in the next 30 minutes at $2000 \mathrm{xg}$ and $4{ }^{\circ} \mathrm{C}$ for $20 \mathrm{~min}$, obtaining serum and plasma. An antioxidant cocktail ( $10 \%$ volume) was added to plas$\mathrm{ma}$, and samples were stored at $-80^{\circ} \mathrm{C}$ until analysis.

\section{Assays}

MDA plasma levels $(\mu \mathrm{M})$ were determined by high performance liquid chromatography (Chromsystem Instrument \& Chemical Gmbh Heimbrugstrasse, Munich, Germany). Proteins were precipitated, a chromogen was added to the supernatant, detecting the resulting compound by an ultraviolet detector. The intra and inter-assay coefficient of variation (CV) were $4.7 \%$ and $8.5 \%$, respectively.

$\mathrm{LOOH}$ were extracted from plasma using chloroform, reacted with ferrous ions, and the resulting ferric ions were quantified $(\mu \mathrm{M})$, using thiocianate, by spectrophotometry. The intra and inter-assay CV were $<5 \%$ and $10 \%$, respectively.

CP levels $(\mu \mathrm{M})$ were determined using 2,4-dinitrophenyl-hydrazine (DNPH) as a result of the difference in absorbance at $365 \mathrm{~nm}$ between DNPH-treated samples and HCl-treated controls, with $\varepsilon_{370}=22.000$ $\mathrm{M}^{-1} \mathrm{~cm}^{-1}$. The intra and inter-assay $\mathrm{CV}$ were $4.7 \%$ and $8.5 \%$, respectively (Cayman Chemical Company, Ann Arbor, USA. Lipid hydroperoxide (LPO) and Carbonyl Protein assay kit).

Serum samples were used to perform traditional RA biomarkers: RF (IU/mL, intra and inter-assay $\mathrm{CV}$ were $<3.4 \%$ and $<3.5 \%$, respectively) and C-reactive protein (CRP) $(\mathrm{mg} / \mathrm{L}$, intra and inter-assay CV were $<5.2 \%$ and $<5.1 \%$, respectively) by inmunoturbidimetry (Bayer HealthCare, New York, USA). Anti-CCP (IU, intra and inter-assay CV were $<8.0 \%$ and $<7.0 \%$ respectively) $3^{\text {rd }}$ generation were performed by ELISA (INOVA Diagnostics, Inc., San Diego, USA).

\section{Statistical methods}

For descriptive purpose, median and interquartile range (IQR) in case of normality or mean and standard deviation (SD) in 
case of non-normality for continuous variables were used. Relative percent frequencies were used for categorical variables. The Wilcoxon matched-pairs signed-ranks and the McNemar tests were used to compare continuous and dichotomous variables between case and control groups, respectively. Binary logistic regression models were used for the analysis in which RA diagnosis was the dependent variable and the traditional- and oxidative stress markers were included as independent variables. Sensitivity and specificity were calculated using ROC curves. This analysis was performed in agreement with the STARD initiative ${ }^{9}$. Statistical analysis was performed using the STATA package v-10 and SPSS v-19.

\section{RESULTS}

Sixty five DMARD and glucocorticoids naive RA patients and 65 healthy controls were included in the study. Patients were statistically significant different to controls in age, oxidative stress biomarkers, smoking-dose (pack/years) and RA related variables. No statistical significant differences between patients and controls were found regarding gender and smoking habit (never, ever or current) (Table 1). These results are the same whether patients are divided into subgroups with respect to smoking or anti-CCP antibodies positive or negative when compared with the healthy control group (Table 1). No significant differences in the classic markers of RA among patients according to sex were found (data not shown).

Table 1. Socio-demographic characteristics and serum levels of biormakers

\begin{tabular}{|c|c|c|c|c|c|c|}
\hline Parameters & $\begin{array}{c}\text { RA } \\
\text { patients } \\
(\mathrm{n}=65) \\
\text { Median (IQR) }\end{array}$ & $\begin{array}{c}\text { RA smoker } \\
\text { patients } \\
(\mathrm{n}=22) \\
\text { Median (IQR) }\end{array}$ & $\begin{array}{l}\text { RA non-smokers } \\
\text { patients } \\
(\mathrm{n}=43) \\
\text { Median }(\mathrm{IQR})\end{array}$ & $\begin{array}{c}\text { RA anti-CCP } \\
\text { positive patients } \\
(\mathrm{n}=34) \\
\text { Median (IQR) }\end{array}$ & $\begin{array}{c}\text { RA anti CCP } \\
\text { negative patients } \\
(\mathrm{n}=31) \\
\text { Median (IQR) }\end{array}$ & $\begin{array}{c}\text { Healthy } \\
\text { Controls } \\
(\mathrm{n}=65) \\
\text { Median (IQR) }\end{array}$ \\
\hline Age (years) & $50(43-63)^{*}$ & $50(43-56)$ & $49(43-64)$ & $50(43-63)^{*}$ & $50(43-64)^{*}$ & $50(41-60)$ \\
\hline CRP (mg/L) & $9.2(3.4-25.4)^{*}$ & $8.9(4.0-14.0)^{*}$ & $7.6(2.2-31.3)^{*}$ & $8.9(4.8-14.8)^{*}$ & $7.3(1.1-29.5)^{*}$ & $1.0(0.4-4.6)$ \\
\hline $\mathrm{LOOH}(\mu \mathrm{M})$ & $36.2(26.7-51.2)^{*}$ & $37.4(28.7-45.3)^{*}$ & $36.2(23.6-52.7)^{*}$ & $35.3(22.9-52.1)^{*}$ & $39.7(27.3-51.2)^{*}$ & $16.7(8.4-29.2)$ \\
\hline $\mathrm{CP}(\mu \mathrm{M})$ & $112.2(59.1-147.0)^{*}$ & $106.2(52.8-141.5)^{*}$ & $114.5(62.8-150.8)^{*}$ & $108.7(49.7-147.0)^{*}$ & $114.5(65.8-150.8)^{*}$ & $46.0(25.1-68.2)$ \\
\hline \multirow[t]{2}{*}{$\mathrm{MDA}(\mu \mathrm{M})$} & $8.0(6.7-8.6)^{*}$ & $7.4(6.7-8.5)^{*}$ & $8.1(6.7-9.0)^{*}$ & $8.1(6.7-8.4)^{*}$ & $7.7(6.8-9.7)^{*}$ & $9.1(8.5-10.1)$ \\
\hline & n (\%) & n (\%) & n (\%) & n (\%) & n (\%) & n (\%) \\
\hline Gender (female) & $51(79)$ & $15(68)$ & $36(84)$ & $26(76)$ & $25(81)$ & $51(79)$ \\
\hline \multicolumn{7}{|l|}{ Smoking habit } \\
\hline Never & $30(46)$ & $0(0)$ & $30(70)$ & $14(41)$ & $16(52)$ & $35(54)$ \\
\hline Ever & $13(20)$ & $0(0)$ & $13(30)$ & $6(18)$ & $7(22)$ & $7(11)$ \\
\hline Current & $22(34)$ & $22(100)$ & $0(0)$ & $14(41)$ & $8(26)$ & $23(35)$ \\
\hline $\begin{array}{c}\text { Smoking dose } \\
\text { (pack year) } \\
\leq 20 \\
>20\end{array}$ & $\begin{array}{l}44(68)^{*} \\
21(32)^{*}\end{array}$ & $\begin{array}{l}7(22)^{*} \\
15(68)\end{array}$ & $\begin{array}{c}37(86)^{*} \\
6(14)\end{array}$ & $\begin{array}{c}21(62)^{*} \\
13(38)\end{array}$ & $\begin{array}{l}8(26)^{*} \\
23(74)\end{array}$ & $\begin{array}{c}60(92) \\
5(8)\end{array}$ \\
\hline $\begin{array}{c}\text { Shared epitope } \\
\text { Positive } \\
\text { Negative }\end{array}$ & $\begin{array}{c}34(52)^{*} \\
31(48)\end{array}$ & $\begin{array}{c}13(59)^{*} \\
9(21)\end{array}$ & $\begin{array}{c}20(46)^{*} \\
23(54)\end{array}$ & $\begin{array}{c}17(50)^{*} \\
17(50)\end{array}$ & $\begin{array}{c}16(52)^{*} \\
15(48)\end{array}$ & $\begin{array}{l}20(31) \\
45(69)\end{array}$ \\
\hline $\begin{array}{l}\text { Anti-CCP } \\
\text { (positive) }\end{array}$ & $33(51)^{*}$ & $14(64)^{*}$ & $20(46)^{*}$ & $34(100)^{*}$ & $0(100)$ & $0(0)$ \\
\hline RF (positive) & $41(63)^{*}$ & $16(73)^{*}$ & $25(58)^{*}$ & $27(79)^{*}$ & $14(45)^{*}$ & $4(7)$ \\
\hline
\end{tabular}

$\mathrm{RA}=$ rheumatoid arthritis, $\mathrm{CRP}=\mathrm{C}$-reactive protein, $\mathrm{LOOH}=$ lipid hydroperoxides, $\mathrm{CP}=$ carbonyl protein, $\mathrm{MDA}=$ malonyldialdehyde, Anti-CCP = anti-cyclic citrullinated peptide, $\mathrm{RF}=$ rheumatoid factor.

*statistically significant differences $(\mathrm{p}<0.01)$ compared to the control group. 
Mean \pm SD for disease variables in patients were as follows: symptoms duration $9.0 \pm 4.6$ months; number of tender and swollen joints $10.7 \pm 7.4$ and $8.8 \pm 1.2$, respectively; patients' visual analogue scale (VAS) of RA $57.7 \pm 25.2 \mathrm{~mm}$; physician ${ }^{\prime}$ VAS of RA inflammation $50.8 \pm 22.9 \mathrm{~mm}$; disease activity score of four variables with C-reactive protein (DAS28_CRP) $4.8 \pm 1.5$; Health Assessment Questionnaire (HAQ) $1.4 \pm 0.8$.

Diagnostics performance of different variables and logistic regression models for diagnostic of RA are shown in table 2 . The shared epitope showed significant differences between patients and controls (table 1), but did not provide diagnostic utility. Due to the contradictory results of MDA, this was not used to build logistic regression models. As expected, the diagnosis performance of traditional markers (RF, anti-CCP, CRP) showed good specificity but relatively low sensitivity. The addition of $\mathrm{LOOH}$ and $\mathrm{CP}$ (in lower grade) increased the sensitivity.

Furthermore, this sensitivity improvement was higher in the subgroup of RA patients with negative anti-CCP $(n=31)$, in which the addition of $\mathrm{LOOH}$ and $\mathrm{CP}$ to classical biomarkers substantially improved diagnostic performance. Similar results were found in the subgroup of non-smokers RA patients $(n=43)$. Finally, traditional RA serological markers were more useful in smokers than non-smokers (AUC 0.966 (0.922-1.000) vs. 0.878 (0.803$0.954), \mathrm{p}=0.048)$. In the subgroup of smokers, sensitivity, specificity and area under the ROC curve did not increase when markers of oxidative damage were added to the model (Table 2).

\section{DISCUSSION}

In this study, we assessed the additional diagnostic value of oxidative stress markers for diagnosing patients with RA, in addition to avoiding the influence of the treatment have been selected patients who have no DMARD, glucocorticoid or antioxidant treatment. The classical markers showed the expected diagnosis per- formance for a sample of patients with early $\mathrm{RA}^{1}$, where the addition of anti-CCP has not led to significant improvements in sensitivity ${ }^{10,11}$. As previously reported, both $\mathrm{LOOH}^{12}$ and $\mathrm{CP}^{13}$ were elevated in $\mathrm{RA}$ patients. Separately, $\mathrm{LOOH}$ and $\mathrm{CP}$ had better sensitivity but much lower specificity than traditional biomarkers. Due to the contradictory results of $\mathrm{MDA}^{14}$, was not used to build logistic regression models because it showed no diagnostic accuracy and also showed very low area under the roc curve (Table 2 ). When the three classical markers and oxidative damage biomarkers were added into the same model, diagnostic accuracy in recent-onset RA patients increased, especially due to sensitivity raise. The best performance of the oxidative stress markers was for $\mathrm{LOOH}$ while CP marginally improved the accuracy of classical model, but not that already includes $\mathrm{LOOH}$. A similar but reinforced behavior of oxidative damage biomarkers was observed in case of negative anti-CCP and non-smoking habit.

Thus, good sensitivity and specificity was observed when using together traditional markers and $\mathrm{LOOH}$, especially in negative anti-CCP or non-smokers patients. Based on our initial hypothesis, these results show that oxidative damage markers can help to early diagnosis of RA when sensitivity is required or anti-CCP antibodies are negative. Other studies reported results in the same way but they only focused on sensitivity and specificity and included patients with DMARD or steroids which have an antioxidant effect or were not in an early stage of the disease $^{15}$. The most important strengths of our study are that all patients had not received any antioxidant treatment and had a recent onset of the disease.

Furthermore, due to the observed effect in non-smokers, it appears that oxidative stress contributes to the development of the disease as an independent factor of tobacco consumption. This result is consistent with our previous work $^{14}$ in which we reported an interaction between tobacco and oxidative stress with an increase risk of RA development. Moreover, 
Table 2. RA Diagnostic performance and logistic models in total population, anti-CCP negative RA patients and non-smokers patients vs. controls

\begin{tabular}{|c|c|c|c|c|c|c|c|c|}
\hline & Parameter or model & Cut-off & S (\%) & Sp (\%) & $\mathrm{LH}+$ & LH- & $\mathrm{AUC}(95 \% \mathrm{Cl})$ & $\mathbf{P}$ \\
\hline \multirow{10}{*}{$\begin{array}{c}\text { Total } \\
\text { population }\end{array}$} & $\mathrm{RF}$ & $20.0 \mathrm{UI} / \mathrm{mL}$ & 64.6 & 87.7 & 5.25 & 0.40 & $0.802(0.722-0.881)$ & \\
\hline & anti-CCP & $20.0 \mathrm{IU}$ & 52.3 & 98.5 & 34.00 & 0.48 & $0.780(0.700-0.860)$ & \\
\hline & CRP & $5.0 \mathrm{mg} / \mathrm{L}$ & 67.7 & 78.5 & 3.14 & 0.41 & $0.808(0.734-0.881)$ & \\
\hline & $\mathrm{LOOH}$ & $29.3 \mu \mathrm{M}$ & 69.2 & 78.5 & 3.21 & 0.39 & $0.758(0.675-0.829)$ & \\
\hline & $\mathrm{CP}$ & $58.0 \mu \mathrm{M}$ & 76.9 & 70.8 & 2.63 & 0.33 & $0.791(0.711-0.858)$ & \\
\hline & MDA & $8.5 \mu \mathrm{M}$ & 30.8 & 24.6 & 0.41 & 2.81 & $0.236(0.150-0.322)$ & \\
\hline & $\mathrm{RF}+$ anti-CCP+CRP & & 78.5 & 92.3 & 10.20 & 0.23 & $0.908(0.855-0.962)$ & reference \\
\hline & $\mathrm{RF}+$ anti-CCP+CRP+LOOH & & 86.2 & 93.8 & 14.01 & 0.15 & $0.951(0.917-0.985)$ & $0.035^{*}$ \\
\hline & $\mathrm{RF}+$ anti- $\mathrm{CCP}+\mathrm{CRP}+\mathrm{CP}$ & & 81.5 & 93.8 & 13.26 & 0.20 & $0.934(0.893-0.974)$ & 0.082 \\
\hline & $\mathrm{RF}+$ anti-CCP+CRP+LOOH+CP & & 86.2 & 93.8 & 14.01 & 0.15 & $0.959(0.928-0.990)$ & $0.020^{*}$ \\
\hline \multirow{8}{*}{$\begin{array}{l}\text { Anti-CCP } \\
\text { negative } \\
\text { patients }\end{array}$} & $\mathrm{RF}$ & $20.0 \mathrm{UI} / \mathrm{mL}$ & 48.4 & 87.7 & 3.93 & 0.59 & $0.730(0.614-0.845)$ & \\
\hline & CRP & $5.0 \mathrm{mg} / \mathrm{L}$ & 61.3 & 76.9 & 1.99 & 0.52 & $0.774(0.668-0.880)$ & \\
\hline & $\mathrm{LOOH}$ & $22.5 \mu \mathrm{M}$ & 87.1 & 64.6 & 2.46 & 0.20 & $0.771(0.689-0.839)$ & \\
\hline & $\mathrm{CP}$ & $52.8 \mu \mathrm{M}$ & 96.8 & 63.1 & 2.62 & 0.05 & $0.836(0.761-0.895)$ & \\
\hline & $\mathrm{RF}+\mathrm{CRP}$ & & 54.8 & 93.8 & 8.83 & 0.48 & $0.820(0.717-0.923)$ & reference \\
\hline & $\mathrm{RF}+\mathrm{CRP}+\mathrm{LOOH}$ & & 71.0 & 93.8 & 11.45 & 0.31 & $0.903(0.834-0.972)$ & $0.049^{*}$ \\
\hline & $\mathrm{RF}+\mathrm{CRP}+\mathrm{CP}$ & & 64.5 & 92.3 & 8.38 & 0.38 & $0.884(0.814-0.954)$ & 0.061 \\
\hline & $\mathrm{RF}+\mathrm{CRP}+\mathrm{LOOH}+\mathrm{CP}$ & & 71.0 & 92.3 & 9.22 & 0.31 & $0.918(0.854-0.982)$ & $0.022^{*}$ \\
\hline \multirow{9}{*}{$\begin{array}{l}\text { Non-smokers } \\
\text { patients }\end{array}$} & $\mathrm{RF}$ & $20.0 \mathrm{UI} / \mathrm{mL}$ & 60.5 & 87.7 & 4.91 & 0.45 & $0.752(0.646-0.858)$ & \\
\hline & anti-CCP & $20.0 \mathrm{IU}$ & 46.5 & 98.5 & 30.23 & 0.54 & $0.728(0.625-0.831)$ & \\
\hline & CRP & $5.0 \mathrm{mg} / \mathrm{L}$ & 72.1 & 67.9 & 2.23 & 0.41 & $0.795(0.709-0.881)$ & \\
\hline & $\mathrm{LOOH}$ & $22.5 \mu \mathrm{M}$ & 81.4 & 79.8 & 4.03 & 0.23 & $0.783(0.697-0.854)$ & \\
\hline & $\mathrm{CP}$ & $52.4 \mu \mathrm{M}$ & 88.4 & 69.1 & 2.86 & 0.17 & $0.855(0.777-0.913)$ & \\
\hline & $\mathrm{RF}+$ anti-CCP+CRP & & 69.8 & 96.9 & 22.52 & 0.31 & $0.878(0.803-0.954)$ & reference \\
\hline & $\mathrm{RF}+$ anti-CCP+CRP+LOOH & & 76.7 & 93.9 & 12.57 & 0.25 & $0.934(0.885-0.982)$ & $0.05^{*}$ \\
\hline & $\mathrm{RF}+$ anti-CCP+CRP+CP & & 74.4 & 98.5 & 49.60 & 0.26 & $0.911(0.856-0.967)$ & 0.10 \\
\hline & $\mathrm{RF}+$ anti-CCP+CRP+LOOH+CP & & 79.1 & 93.8 & 12.75 & 0.22 & $0.948(0.906-0.990)$ & $0.02^{*}$ \\
\hline \multirow{9}{*}{$\begin{array}{l}\text { Smokers } \\
\text { patients }\end{array}$} & $\mathrm{RF}$ & $20.0 \mathrm{UI} / \mathrm{mL}$ & 77.3 & 91.3 & 8,885 & 0,24 & $0.927(0.849-1.000)$ & \\
\hline & anti-CCP & $20.0 \mathrm{IU}$ & 68.2 & 91.3 & 7,839 & 0,34 & $0.907(0.806-1.000)$ & \\
\hline & CRP & $5.0 \mathrm{mg} / \mathrm{L}$ & 54.6 & 82.6 & 3,137 & 0,54 & $0.808(0.678-0.939)$ & \\
\hline & $\mathrm{LOOH}$ & $22.5 \mu \mathrm{M}$ & 59.1 & 69.6 & 1,944 & 0,58 & $0.700(0.542-0.857)$ & \\
\hline & $\mathrm{CP}$ & $52.4 \mu \mathrm{M}$ & 59.1 & 73.9 & 2,264 & 0,55 & $0.677(0.516-0.837)$ & \\
\hline & $\mathrm{RF}+$ anti-CCP+CRP & & 90.9 & 95.6 & 20,66 & 0,10 & $0,972(0,933-1,000)$ & reference \\
\hline & $\mathrm{RF}+$ anti-CCP+CRP+LOOH & & 90.9 & 95.6 & 20,66 & 0,10 & $0,984(0,955-1,000)$ & 0,411 \\
\hline & $\mathrm{RF}+$ anti-CCP+CRP+CP & & 90.9 & 95.6 & 20,65 & 0,10 & $0,984(0,959-1,000)$ & 0,370 \\
\hline & $\mathrm{RF}+$ anti-CCP+CRP+LOOH+CP & & 95.4 & 100.0 & - & 0,05 & $0,988(0,963-1,000)$ & 0,337 \\
\hline
\end{tabular}

$\mathrm{RF}$ rheumatoid factor, anti-CCP anti cyclic citrullinated peptide antibodies, CRP C reactive protein, LOOH lipid hydroperoxides, CP carbonyl protein, S Sensibility, Sp Specificity, LH likelihood ratio, AUC area under ROC curve, CI confidence interval, ${ }^{*} \mathrm{P}$ value for AUC compared to the reference model in each group. 
recent studies associated smoking to the emergence of anti-CCP ${ }^{16}$, but not $\mathrm{RF}^{17}$, in patients with a specific HLA-DR (shared epitope) background, suggesting an etiology role of tobacco restricted to this risk genetic factor ${ }^{18}$. In our group, there are significant differences in the shared epitope but showed no diagnostic utility. In our patients, the addition of $\mathrm{LOOH}$ and $\mathrm{CP}$ to classical biomarkers increased significantly diagnostic accuracy in non-smokers while provide no useful information in smokers. These results appear to reflect the association between anti-CCP and smoking in the disease.

The results of this study are limited by relative small sample size, because of the difficulty to recruit patients without previously DMARD or glucocorticoid treatment. However control sample is representative of the population actually at risk of having the disease, not of the general population because of study design ${ }^{19}$. Another limitation of the study is the lack of standardization of methods of measurement of various markers, although the methods were the same for patients and controls.

In conclusion, this study evaluated the diagnosis performance of oxidative damage markers ( $\mathrm{LOOH}$ and $\mathrm{CP}$ ) in early RA patients. The separately or combined addition of these two oxidative damage markers to the traditional disease markers (RF, Anti-CCP, CRP) improved the diagnosis of RA, especially in the cases that sensitivity is required in order to discard the disease in negative anti-CCP patients or non-smokers. Therefore, although the results of this study provide new evidence for including oxidative damage markers, $\mathrm{LOOH}$ and $\mathrm{CP}$, as new tools to be included in the diagnostic process or early RA, further studies with larger numbers of individuals are needed to confirm them.

\section{Acknowledgments}

The authors would like to thank all participants who took part in this study. We also thank Mr. Christian Leyva Prado, Mrs. Carmen González-Martín and Mr. Fernando Fabiani Romero for their technical support.

\section{REFERENCES}

1. Aletaha D, Neogi T, Silman AJ, Funovits J, Felson DT, Bingham CO et al. Rheumatoid arthritis classification criteria: an American College of Rheumatology/ European League Against Rheumatism collaborative initiative. Ann Rheum Dis 2010; 69: 1580-1588.

2. Klareskog L, Padyukov L, Alfredsson L. Smoking as a trigger for inflammatory rheumatic diseases. Curr Opin Rheumatol 2007; 19: 49-54.

3. Källberg H, Ding B, Padyukov L, Bengtsson C, Rönnelid J, Klareskog L, Alfredsson L. Smoking is a major preventable risk factor for rheumatoid arthritis: estimations of risks after various exposures to cigarette smoke. Ann Rheum Dis 2001; 70: 508-511.

4. Costenbader KH, Karlson EW. Lupus 2006; 15 : 737-745.

5. Cedergren J, Forslund T, Sundqvist T, Skogh T. Intracellular oxidative activation in synovial fluid neutrophils from patients with rheumatoid arthritis but not from other arthritis patients. J Rheumatol 2007; 34: 2162-2170.

6. SARban S, Kocyigit A, YAZAR M, IsIKan UE. Plasma total antioxidant capacity, lipid peroxidation, and erythrocyte antioxidant enzyme activities in patients with rheumatoid arthritis and osteoarthritis. Clin Biochem 2005; 38 : 981-986.

7. Cerhan JR, SaAg KG, Merlino LA, Mikuls TR, CRISWELl LA. Antioxidant micronutrients and risk of rheumatoid arthritis in a cohort of older women. Am J Epidemiol 2003; 157: 34554.

8. Comstock GW, Burke AE, Hoffman SC, HelzlsoNER KJ, BENDich A, MASI AT et al. Serum concentrations of alpha tocopherol, beta carotene, and retinol preceding the diagnosis of rheumatoid arthritis and systemic lupus erythematosus. Ann Rheum Dis 1997; 56: 323-325.

9. Bossuty PM, Reitsma JB, Bruns DE, Gatsonis CA, Glasziou PP, Irwing LM et al. Towars complete an accurate reporting of studies of diagnostic accuracy: The STARD Initiative. Ann Intern Med 2003; 138: 40-44.

10. Matsui T, Shimada K, Ozawa N, Hayakawa H, HaGIWARA F, NAKAYAMA $\mathrm{H}$ et al. Diagnostic utility of anti-cyclic citrullinated peptide antibodies for very early rheumatoid arthritis. J Rheumatol 2006; 33: 2390-2397.

11. Hodkinson B, Musenge PWA, Ally MMt, Wadee AA, Anderson R, TikLy M. The diagnostic utility of the anti-CCP antibody test is no better than rheumatoid factor in South Africans with early rheumatoid arthritis. Clinical Rheumatology 2010; 29: 615-618. 
12. IsIK SS, Koca B, Ustundag H, Yildirim AC. Paraoxonase and arylesterase levels in rheumatoid arthritis. Clin Rheumatol 2007; 26: 342-348.

13. Lemarechal H, Allanore Y, Chenevier-Gobeaux C, KaHAN A, Ekindian OG, Borderie D. Serum protein oxidation in patients with rheumatoid arthritis and effects of infliximab therapy. Clin Chim Acta 2006; 372: 147-153.

14. Navarro-Compán MV, Melguizo-Madrid E, HernÁndez-Cruz B, Santos-Rey K, Leyva-Prado C, GonZÁLEZ-MARTín $\mathrm{C}$ et al. Interaction between oxidative stress and smoking is associated with rheumatoid arthritis. A case - control study. Rheumatology 2013; 52: 487-493.

15. Seven A, Güzel S, Aslan M, Hamuryudan V. Lipid, protein, DNA oxidation and antioxidant status in rheumatoid arthritis. Clin Biochem 2008; 41: 538-543.
16. Zsuzsanna B, BuZÁs E, NAGY G. Rheumatoid arthritis and smoking: putting the pieces together. Arthritis Res Ther 2009; 11: 238-250.

17. Lee DM, Phillips R, Hagan EM, Chibnik LB, CosTENBADER KH, Schur PH. Quantifying anti-cyclic citrullinated peptide titres: clinical utility and association with tobacco exposure in patients with rheumatoid arthritis. Ann Rheum Dis 2009; 68: 201-208.

18. Klareskog L, Stolt P, Lundberg K, Kallberg H, Bengtsson C, Grunewald J. A New model for an etiology of rheumatoid arthritis. Smoking may trigger hla-dr (shared epitope)-restricted immune reactions to autoantigens modified by citrullination. Arthritis Rheum 2006; 54: 38-46.

19. Bencina MJ. Caution is needed in the interpretation of added value of biomarkers analyzed in matched case control studies. Clin Chem 2012; 58: 1176-1178. 
